\title{
Management of the Natural Attractions in the Area Simarjarunjung Simalungun North Sumatra Province
}

\author{
Rinal Kusnadi \\ Student, Faculty of Forestry, University of North Sumatra, Indonesia
}

\begin{abstract}
Nature is the utilization of natural resources and environmental governance has been defined as the object of tourist attraction and to be made the target of tourism potential. The natural potential in Indonesia is very diverse, one of which is the potential of Nature Tourism in North Sumatra. Natural potential that is being developed is only one Nature in The Simarjarunjung. This study aims to determine how the institutional management of the Natural Attractions in the Area Simarjarunjung Simalungun Regency and utilization of natural resources on the activities of the Nature in The Simarjarunjung Simalungun. This research method is qualitative using institutional theory has aspects of that structure, shape and norms. The utilization of natural resources using the theory states there are four aspects, namely, the common property, state property, private property and the common property. The result of this research is the institutional management of the Natural Attractions in The Simarjarunjung have the management of the Combined Forest Farmer Group and the Group Aware of Its Loyal Both as a driver and manager. Natural attractions in The Simarjarunjung managed group and personal with having the structure of the management. Natural resources in the Region's Nature Simarjarunjung have natural resources that is different such is the charm of nature, the mountains, the pine stands, agro-forestry plants and microclimate. The utilization of these natural resources will continue to be managed to improve the local economy.
\end{abstract}

Keywords: Nature, Simarjarunjung, Institutional Management, Natural Resources

\section{INTRODUCTION}

Nature is the utilization of natural resources and environmental governance has been defined as the object of tourist attraction and to be made the target of those places. Nature tourism in Indonesia is very diverse, one of which is the potential of Nature Tourism in North Sumatra. The natural potential of being developed one of the Natural Attractions Simarjarunjung. Nature tourism many tourists because tourism has one of the places that favorite to see the landscape of Lake Toba and the tourist attraction is one of the attractions located in the Village Parik Sabungan, Simalungun Regency, Sumatera Utara (Damanik, 2018).

The development of tourism has an important role as a revenue generator for the community and tourism is highly dependent of the level of community involvement in the development of a tourist destination. The development of tourism involves all layers of society and government. The role of government as a facilitator, providing infrastructure and people understand that with the perlibatan will get the benefits of positive and would be interested in supporting and encouraging the development of tourism to promote tourism destinations (Nawawi, 2013).

The public can participate in the management of nature through the institutional community-based as well as can emphasize the institutional infrastructure in the settings for the institutional mechanism, then such a system 
can thrive. Such systems play an important role in regulating the relationship between the human and natural resources, so that it can continue to function and make sure that the interpersonal relationships in the community remain harmonious (Muhtadi et al., 2016)

The importance of an institution is in need of an institutional approach in addressing poverty to emphasize how social resources can be grown with the need of an institution that has the responsibility for the realization of strategy and policy. Natural attractions in The Simarjarunjung with the establishment of the institution is as a driver and manager for kelompook and individuals. This nature has a Forest Farmer Group that is very active role in the improvement of community-based tourism (Noor, 2017).

The formation of the institution of the then Forest Farmer Group has played an important role in the management of Natural Attractions in The Simarjarunjung. The important role of Forest Farmer Group in the management of Natural Attractions Simarjarunjung is mutually cooperate in the development and management of nature and harness the potential of natural resources. The presence of institutional formed then it can form a pattern of behavior to the community, the institutional greatly contribute in supporting all the fulfillment for the sake of the welfare of the community is increasing as well as improving natural resources (Nikoyen et al., 2020).

Natural resources that there is anything in nature that can be utilized by the community and can help as a source of life. The potential of natural resources then it is very essential to do the management. Natural resources there are two important things to do is the utilization and supervision. The utilization of natural resources indicated solely to improve the welfare of the community, while in the presence of an oversight in the management of the natural resources that are negative. The availability of natural resources it will be able to cope with economic development and sustainable development for the welfare of society (Katili, 2009).

As the important role of the institutional to the management of natural resources. Institution in the society then it is very easy to manage and increase the potential of natural resources to raise awareness and to raise awareness of the potential of nature and natural resources. Institutional functions give the code of conduct to the community and improve the economy of the community with how to manage natural resources as well as using the techniques. Natural resource management should be applied in the community so that the community understand how the management of natural resources and develop the potential that exists (Saroinsong et al., 2016).

\section{LITERATURE REVIEW Tourism Management}

Based on the statement of Djogo el al., (2003) stated that in general the definition of the institution includes the concept of patterns of social behavior and is ongoing. Institutional contains two important aspects, namely the institutional aspects and aspects of the organization. Institutional aspects include social behavior where the core of the study is about the value (value), norm (norm), custom, folkways, usage, belief, idea, doctrine, desires, needs and orientation. While aspects of the organization, including structure and social structure with the core of the study lies in the aspects of the role (Damayanti et al., 2016).

\section{Forest Farmer Group}

Forest Farmer group is a collection of farmers who manage the business in the field of forestry in the inside and outside of the forest area which include timber, nontimber forest products and environmental services. The people who live in the forest area in general is a group of society that is relatively lagging behind in social and economic compared to the left with other community groups. People use the forest as 
an alternative source of income by way of through the benefits of timber and nontimber forest products (Ginting et al., 2014).

\section{The Utilization And Management Of Natural Resources}

Natural resource is anything that comes from nature that can be used to meet the needs of human life. Natural resources play an important role in the formation of the human life, so that every culture and ethnicity have the conception and world views of its own about the control and management of natural resources. In general, the governance of natural resources is carried out by an indigenous community recognize the existence of diverse status of the mastery and utilization. The shape and status of the mastery of the natural resources can be divided into four groups, namely common property, private property, state property and belongs to the group of (Hidayat, 2011).

\section{Utilization Of Forest Resources}

Forest exploitation activities to utilize forest areas, utilizing the services of the environment, utilizing timber and nontimber forest products as well as picking up timber and non-timber optimal and fair to the welfare of the community while maintaining sustainability. The role of the forest can indirectly we can feel with evidence that the forest is the provision of oxygen, water regulator, the supply of oxygen and a source of fulfillment (Ariani et al., 2012).

\section{The Management Of Tourist Attraction}

Management is a process that provides oversight on all matters involved in the implementation of the wisdom and the achievement of goals. Tourism management harusla refers to the management principles that emphasize the values of environmental sustainability, communication and social value that allows the tourists who enjoy activities and tourism, as well as beneficial for the welfare of the local community. The construction and development of tourism must be based on local wisdom that reflects the uniqueness of the cultural heritage and the uniqueness of the environment. Management of tourism, Law number 32 of article 1 of the year 2009 on environmental protection and management that attempts to systematically and integrated is done to preserve function and prevent environmental damage (Kairupan et al., 2018).

\section{Community-Based Ecotourism}

Community-based ecotourism is a business of ecotourism which emphasizes the active role of the community. It is based on the fact that the public has knowledge about the nature and culture that become the potential and value as a tourist attraction, so the involvement of the community to be absolute. Forecast community-based ecotourism recognize the rights of local communities in managing tourism activities in the area they have by custom as a manager. The presence of patterns of community-based ecotourism does not mean people will be running the business of ecotourism own, but with the awareness of the community itself (Mardiana et al., 2014).

\section{MATERIAL AND METHODS}

Research has been conducted in the Region's Nature Simarjarunjung, Dolok Pardamean, Simalungun Regency, Sumatera Utara. This research was conducted in the month of December until January 2021. The tool used in this research is stationery, laptops, mobile phones and digital cameras. The materials used in this research is the research location map, guide questions, reports, thesis and thesis previous research and a variety of library materials as a source of secondary data to help supplement direct observation in the field study site.

Data collected in the form of primary data and secondary data. The primary Data obtained from field observations in the form of observations and interviews with stakeholders (community, manager, community leaders, and visitors). 
Secondary Data were collected to complement the primary data through the study of literature to the results of previous research that there is a relation to research, report of the local government (district office and / or the village) text books and so on.

This research is descriptive qualitative with a focus of research on Institutional Management in the Tourist Area of Natural Simarjarunjung. The research is qualitative with this further leads to describe the in-depth information. Based on the statement Gumilang (2016) stated that qualitative research is used to understand social interaction, develop theory, ensure the correctness of the data and researching the history of the development. In accordance with the statement Nugrahani (2014) indicate that qualitative research aims to find the categories and relations that are relevant antarkategori, but do not test the relationship between variables. To get the data in the form of words the researcher conducted interviews with the speakers.

The informant in this research is the community leaders of the Village that the Village Chief and Secretary of the Village. The manager of the natural attractions of the head or chairman of the natural attractions, the surrounding community as well as tourists who visit every attraction of Nature Simarjarunjung are represented, so that the overall number of speakers in the objects of The Natural Attractions Simarjarunjung is 23 speakers. Depth information has been obtained by the author from all the speakers who had been interviewed. This is in accordance with the statement Nugrahani (2014) stated that the interview conducted to the speaker in qualitative research only with the response, information and answers as well as in-depth source of information (resource limited) selected only the knowledge is very profound to the situation and have the information required.

Methods of data collection in this research is as a Survey Method of data Collection that is done through observation and interview methods. The method of direct Observation conducted in the area of Natural Tourist Simarjarunjung Simalungun. Structured interviews with the respondents, namely the tourists and local people who live in the tourist area of Simarjarunjung Simalungun. Interview guidelines used at the time of the interview is the questionnaire so that the questions will be more focused. The type of questions used is the structured interviews and the Method of Literature namely the collection of data can be done by the method of literature study that is a way to obtain data by means of reading literature, reports, scientific papers, and the results of previous research related to the research and Documentation, used for ye at once increase the accuracy, the correctness of the data or information collected from the materials of the existing documentation in the field and can be used as ingredients in checking the validity of data.

\section{RESULTS AND DISCUSSION \\ Management In The Tourist Area Of Natural Simarjarunjung}

Management in the Tourist Area of Natural Simarjarunjung have the management that the Association Works Together which is chaired by the General Tarigan. Farmers' group association is a combination or a collection of farmer groups similar field of business. In addition, the Association is a medium of communication for exchange of information between groups of farmers. The existence of the Association is a social capital that is large enough to build strength at farmer level. The formation of this a movement that emerged from the peasant in an open and transparent, so that with the existence of the Association is then alignments will get back to farmers. The purpose of formation the Association is to provide mentoring, training and facilitating activities, so that people understand what is the meaning of preservation of the environment and the importance of community-based ecotourism. 

province.

A combination of Farmer Groups has a Group of Conscious Wisata is called with the name of the Group Aware of Its Loyal Travel was founded on November 5, 2020. Increase participation and awareness of the Community to manage the environment in the Area of Lake Toba around it, especially in Nagori Parik Sabungan, it is necessary to form a container called Pokdarwis, so the management of all the existing resources as well as the implementation of all planned activities to support organized with the right so that the expected results can be achieved optimally.

The increasing role of the community in tourism development requires a variety of empowerment, so that the community can play a more active role and optimal well as to receive the positive benefits of development activities undertaken to increase their welfare. The purpose terbetuknya Group Conscious Travel Faithful Farmer is as here's:

1. Improve human resources member of Pokdarwis Parik Sabungan united as actors in building tourism so they can work together and partner with stakeholders of the tourism Area.

2. Build and cultivate an attitude and positive support Dusun VI Parik Sabungan in the development of tourism in particular.

3. Utilize as well as preserve the tourist potential of the Nagori Parik Sabungan.

4. Increasing the income of citizens Nagori Parik Sabungan through the development of business Tourism.

Natural attractions in The Simarjarunjung with the status of The Forest in cooperation with KPH II Pematang Siantar. This area is designated by the government to be maintained as a Forest Area. Natural attractions in The Simarjarunjung have both private and group Tours Alam Dolok Sipigul and Nature Pine Hills is managed personally and Nature Simarjarunjung, Nature Dolok Sipintuangin and Bukit Indah Simarjarunjung Annex privately run and have the stewardship.

\section{Institutional Management Of Natural Attractions Dolok Sipigul}

Based on the institutional theory is used according to Meyer and Rowan (1977), which includes several aspects: structure, form and the norm.

\section{The Institutional Structure Of The Nature Tourism Dolok Sipigul}

Natural tourism Dolok Sipigul have a Farmers ' Group Forest Green which was established on 28 November 2017 in accordance with the determination letter Pangulu Nagori Parik Sabungan Dolok Pardamean Simalungun. Power is held by the Annual Meeting of Members, Nature Dolok Sipigul still in the process of application to the Ministry of Environment and KPH II Pematang Siantar, adviser to the Nature Dolok Sipigul said there should be a payment to the State in the form of results production as a condition of use of environmental services. Based on Government Regulation Number 3 Year 2008, establishing the Regulation of the Minister of Environment and Forestry on Guidelines for the Activities of the Utilization of Environmental Services Natural Attractions In Production Forests.

The structure of the KTHH includes protective or trustees, the adviser, the chairman, secretary, treasurer, coordinator of the transport of lymph, the coordinator of mutual cooperation and members. The structure of the KTHH very good, because we have made a meeting of members of the order to the division schedule of activities mutual cooperation.

\section{The form of the institutional Nature Dolok Sipigul}

Natural tourism Dolok Sipigul with the shape of the Farmer Group Forest Green which includes the local community. People who live in the surrounding forest Dolok Sipigul who reside in particular Dusun VI Sipintuangin Village Parik Sabungan Dolok Pardamean Simalungun which are listed in the group and have the passion and efforts to preserve the forest and the head of each family is a member of the KTHH. 
Become a member KTHH first make a statement to members of the KTHH signed on stamp Rp. 6000,-. People that have been joined with KTHH should be responsible for the authority that has been given as provided in the articles of association (AD) and bylaws (ART).

\section{a. The process of the community in the running of the KTHH}

After the community join in $\mathrm{KTHH}$, people should always follow the activities there. As for the activities KTHH is as follows:

1. To manage and utilize non-timber forest products in the form of the sap of pine trees in the area of partnership of forestry in accordance with applicable regulations.

2. Manage and utilize forest areas with plants agroforestry other as well as plants citronella, coffee, corn, ginger, plants forestry and agro-forestry plants other as well as the processing of honey bees in the area of partnership of forestry in accordance with applicable regulations.

3. Implement forest protection in the area in and around the location of the partnership forestry either the prevention of forest fire, encroachment of forest areas, felling of trees without the permission and wildlife poaching.

4. Keep the conduciveness of the implementation of activities in the area of partnership of forestry.

5. Carry out the obligations of the other obligations in accordance with the agreement and applicable laws and regulations

6. Solve the problems according to the rules or for family in case of land disputes with the public or other parties.

\section{b. The purpose of the Farmer Group Forest Green (KTHH)}

The purpose of KTHH is as follows:

1. Collect all forest communities who cultivate land owned by forestry in order to obtain legal protection of the
Government in this case the Ministry of Environment and Forestry UNIT Forest Management unit Region II Pematang Siantar Department of Forestry North Sumatra Province.

2. Obtain economic and social benefits from the stands of Pine Trees and the activities of agroforestry with regard to the aspects of sustainability that can improve the welfare of the community around the forest.

3. Foster the spirit and consciousness of the nation in order to realize a good citizen.

4. Implement forest protection in the area in and around the location of the partnership forestry either the prevention of forest fire, encroachment of forest areas, felling of trees without a license and hunting wildlife.

5. Do enrichment plants at the forest area which are not productive in collaboration with Government and community Organizations other to advance Nagori Parik Sabungan Dolok Pardamean Simalungun.

The Village community Parik Sabungan always emphasize on the values of togetherness and trust both within an organization and between one organization to another. Run social values on management of Natural Attractions Dolok Sipigul expected to provide help and solutions to problems that arise. Board Travel Dolok Sipigul are expecting the cooperation with the community to improve Its Dolok Sipigul that has huge potential.

According to the adviser KTHH that the people who joined in KTHH have not one thought, because of the results of the management of the pine sap members ask for money from the results of pine resin and a misunderstanding. Duty of trustees is to make the Farmers' Groups into a single thought in the same direction and the same build and develop the Nature Tourism Dolok Sipigul. Tourism development Dolok Sipigul inhibited on the financing of factors, so Its Natural Dolok Sipigul has not been approved as a tourist area. 

province.

Natural tourism Dolok Sipigul not doing community service, so that the Nature Dolok Sipigul still a lot of constraints and shortcomings. Based on the statement of the Dharma et al., (2020) stated that, in view of tourism in the Village Gekbrong've been doing community service, so a lot of visitors who come to tour in the Village Gekbrong. It is stated that, Nature Dolok Sipigul have to do community service, so this nature is known by the surrounding community and to add to the tourists visiting the Natural Attractions Dolok Sipigul.

\section{Tourism Management Bukit Indah Simarjarunjung}

Natural tourism Bukit Indah Simarjarunjung is one among the attractions that be the best spots to witness the panorama of Lake Toba. This tour is managed personally. The institutional Nature of the BIS currently has services Travel destination of Lake Toba was established in the year 2018. Natural attractions the BUS stand with inspired by Natural tourism Kalibiru tourism that is almost similar and can be applied in the Natural Attractions the Bus. Based on the statement Vitasurya et al., (2015) stated that, Kalibiru Tourism has developed into a nature that attracted many people of Kulon Progo.

Natural tourism Kalibiru managed to attract the interest of tourists who want to enjoy the beauty of the view from the top of the hills, enjoying the coolness of the environment and the hospitality of the Village. This case, the Natural Attractions the Bus is not less interesting with other tourist, tourist also enjoy the view from the top of the hills to see the beauty of Lake Toba.

Chairman of the management and advisory Nature Dolok Sipigul expect the cooperation with the University of North Sumatra in terms of community service in Both Dolok Sipigul by mapping the Tourist Area of Dolok Sipigul, so Both Dolok Sipigul can develop quickly. The preservation society is programmed as a process of learning to live in a society. In the beginning of community service as a form of government programs to accelerate the process of national development. In addition to the Government, academics also participate to the community to mempercerpat in the development and help the community through social programs.

\section{The Management Of Natural Attractions Determination Dolok Sipintuangin Simarjarunjung}

\section{Nature Panatapan Dolok}

Sipintuangin was once vacant land that is developed by the owner of the land to be formed as Ecotourism in the Village of Parik Sabungan. The Nature Panatapan Dolok Sipintuangin Simarjarunjung formed in 2018, independently by utilizing the land there.

Based on the institutional theory is used according to Meyer and Rowan (1977), which includes several aspects: structure, form and the norm.

1. The institutional structure of the Nature Tourism Determination Dolok Sipintuangin Simarjarunjung Nature Determination Dolok Sipintuangin not managed in a group and stewardship of the environment is those who have land that is used as a tourist. So this tour does not have a management structure.

2. The form of the institutional Nature Determination Dolok Sipintuangin Simarjarunjung The determination Dolok Sipintuangin is a tourist attraction in the form of the hills, where local residents call it determination. Altitude, visitors can enjoy the view of Lake Toba, the mountains and also spot instagenik for the community and visitors who want to take pictures. The tourist Area of 0.8 hectare, the Determination Dolok Sipintuangin offers a stylish contemporary with a modern design that looks very mesmerizing. Managers of natural attractions Determination Dolok Sipintuangin feel difficulty in managing both, because in the pandemic covid-19 
difficulty in developing tourism and repair facilities. Facilities Natural Attractions Determination Dolok Sipintuangin have constraints, because of the facilities and infrastructure is very minimal. See the development of tourism in the Village Sibunga interest, based on the statement (Darma et al., 2018) stated that, as for the facilities provided in order to meet the needs of tourists such as parking, public toilets, places of worship, as well as the facilities of the stalls and the cottage is both provided by the people of the Village Sibunga-interest. Based on the tourism in the Village Sibunga flower already have all the bik, the thing is, the Determination Dolok Sipintuangin should pay attention to the facilities and infrastructure in order to increase the tourist attraction.

3. Norm institutional or behavior of society about Nature Dolok Sipintuangin Simarjarunjung Based on the Theory of Mayer and Rowan (1977) Nature Determination Dolok Sipintuangin have norms or behavior of the community is called the norm of the law of the single and in pairs what is meant by a legal norm which contains the rules of how we should behave in society.

The behavior of the community is very supportive in the development of Nature Tourism Determination Dolok Sipintuangin by seeking tourist attraction. Attractiveness of the region's Nature Panatapan Dolok Sipintuangin is the view from the view of lake toba from top of the hill. Panatapan Dolok Sipintuangin ideascreative ideas in development so Panatapan Dolok Sipintuangin be one of the natural tourist destinations once travel destination artificial humans unique and interesting by providing a spot for photos, and utilize the landscape of environmental services.

\section{Management Natural tourism Bukit Indah Simarjarunjung Annex}

Based on the institutional theory is used according to Meyer and Rowan (1977), which includes several aspects: structure, form and the norm.

1. The institutional structure of Natural tourism Bukit Indah Simarjarunjung Annex Bukit Indah Simarjarunjung Annex was formed in the year 2018. BIS Annex is not managed on a group basis, but rather for the individual and the arrangement of the structural is they themselves who have both of these.

2. The form of institutional Natural tourism Bukit Indah Simarjarunjung Annex

Natural attractions the Bus Annex used to be and BIS merge into one, and in 2018 the occurrence of separation due to the presence of constraints on the land. This obstacle takes place after a year of natural attractions this walk and constraints are long enough finished and there has been a land acquisition for the road to the location of the Natural Attractions the BUS Annex. The manager expects that the cooperation with the Government for the development of tourism in the form of promoting tourism to the community.

3. The norm or the behavior of the community Natural tourism Bukit Indah Simarjarunjung Annex

Based on the Theory of Mayer and Rowan (1977) the Natural Attractions the BUS Annex has a norm or behavior of the community is called the norm of the law of the single and in pairs what is meant by a legal norm which contains the rules of how we should behave in society.

\section{CONCLUSIONS AND RECOMMENDATIONS CONCLUSIONS}

1. The management of the natural attractions in the Simarjarunjung have the management of the Combined Keompok Farmers and Conscious Group Both as a driver and manager. Natural attractions that exist in The Simarjarunjung managed by the group and which have the structure of 
organizations is the Nature Dolok Sipigul that has a Group of Farmer Green Forest and Nature Pine Forest Hills, which has a Group of Setya Farmer. While both are privately run is the Nature Bukit Indah Simarjarunjung who have a service organization Travel destination of Lake Toba, Dolok Sipintuangin and Bukit Indah Simarjarunjung Annex.

2. The utilization of natural resources in The Simarjarunjung've managed well, because of local communities to manage natural resources into the region's nature. Natural resources in the Tourist Area of Simarjarunjung have natural resources that is different such is the charm of nature, the mountains, the pine stands, agro-forestry plants and microclimate. The utilization of these natural resources will continue to be managed to improve the local economy.

\section{RECOMMENDATIONS}

1. The existence of a Conscious Group Tours in The Nature Simarjarunjung, expected to be able to work together with the government, so there is at Simarjarunjung to get help and encouragement for the management of Natural Attractions in the Simarjarunjung.

2. The presence of Forest Farmer Group in the area of natural tourist simarjarunjung natural resources should be utilized properly for the sake of a better society.

\section{Acknowledgement: None}

\section{Conflict of Interest: None}

\section{Source of Funding: None}

\section{REFERENCES}

1. A Sihombing, $\mathrm{T}$ Sipayung, SE Damanik, $\mathrm{P}$ Nainggolan. 2019. Pengaruh Pembangunan Infrastruktur Jalan, Pertanian Dan Kesehatan Terhadap Pendapatan Asli Daerah (Pad) Di Kabupaten Simalungun. Jurnal Regional Planning. ISSN 2252-553X. Vol 8 (2) 2019.
2. Alam SA, Umar S, Sunarti. 2018. Nilai Ekonomi Kunjungan Objek Wisata Alam Air Terjun Desa Nupabomba Kecamatan Tanantovea Kabupaten Donggala. JOM Fekon. 6 (4) : 533-547.

3. AP Sarintan Efratani Damanik., Marlon Sihombing., Suwardi Lubis. 2017. Planning For Sustainable Waste Management Model In Pematangsiantar City. International Journal of Recent Scientific Research. Vol. 8; Issue. 3; page; 15796-15801.

4. Ariani , Surjono, Ismu RDA. 2012. Bentuk Pengelolaan Sumber daya Hutan di Desa Kololio Kepulauan Togean, Sulawesi Tengah.

5. Badarab TS, Trihayuningtyas E, Suryadana LM. 2017. Strategi Pengembangan Destinasi Pariwisata di KepulauanTogean Provinsi Sulawesi Tengah. Tourism and Hospitality Essentials (THE). 7 (2).

6. Biantoro R, Ma'arif S. 2014. Pengaruh Pariwisata Terhadap Karakteristik Sosial Ekonomi Masyarakat pada Kawasan Objek Wisata Candi Borobudur Kabupaten Magelang. Teknik PWK. 3 (4) : 1038-1047.

7. Budiani RS, Wahdaningrum W, Yosky D, Kensari E, Pratama SH, Mulandari H, Iskandar, Alphabettika M, Maharani N, Febriani FR, Kusmiati Y. 2018. Analisis Potensi dan Strategi Pengembangan Pariwisata Berkelanjutan Berbasis Komunitas di Desa Sembungan, Wonosobo Jawa Tengah. Majalah Geografi Indonesia. 32 (2): 170-176.

8. Damanik BGC. 2018. Fasilitas Objek Wisata Bukit Indah Simarjarunjung Kabupaten Simalungun Provinsi Sumatera Utara, Fakultas Ilmu Sosial dan Ilmu Politik. JOM FISIP. 5 (2) : 1-11.

9. Damanik J, Triambodo S. 2015. Analisis Strategi Penguatan Kelembagaan Desa Wisata Berbasis Ekonomi Kreatif.

10. Damanik, S. E. (2015). Perencanaan pengembangan wisata alam dan pendidikan lingkungan di kawasan hutan Aek Nauli Kecamatan Lumban Julu. Habonaron Do Bona, 1(1), 18.

11. Damanik, S. E. 2009. Studi Sifat Hasil Pembakaran Arang dari Enam Jenis Kayu. Sumatera Utara : LPPM Universitas Simalungun.

12. Damanik, S. E. 2017. Techniques of Efficiency Measurement in Ecology Research of Forest Management Using Data Envelopment Analysis. International Journal 
of Applied Engineering Research ISSN 0973-4562 Volume 12, Number 24 (2017) pp. 16024-16031.

13. Damanik, S. E. 2019. Pemberdayaan Masyarakat Desa Sekitar Hutan. Uwais Inspirasi Indonesia.

14. Damanik, S. E., Purwoko, A., \& Hidayat, R. (2019, March). A mixed integer programming model for forest harvest scheduling problem. In Journal of Physics: Conference Series (Vol. 1175, No. 1, p. 012044). IOP Publishing.

15. Damanik, S. E., Purwoko, A., \& Hidayat, R. (2019, March). A mixed integer programming model for forest harvest scheduling problem. In Journal of Physics: Conference Series (Vol. 1175, No. 1, p. 012044). IOP Publishing.

16. Damanik, S. E., Sahata Purba 2019. Perencanaan Pola Kemitraan Dalam Peningkatan Kesejahteraan Petani Kphxiii Kawasan Doloksanggul Kabupaten Humbang Hasundutan. Sebatik 2621-069X. Vol 23 No 2 (2019): Desember 2019.

17. Damanik, S. E., T Purba. 2020. Peran Penyuluh Kehutanan Dalam Menunjang Keberhasilan Pembangunan Kehutanan (Studi Kasus Desa Pondok Bulu Kabupaten Simalungun). Jurnal Akar. Vol. 2; Issue. 1; page; $1-14$.

18. Damanik, S. E.. (2020, March). Agricultural Ecology of Irrigation Systems and Sustainable Development in Simalungun region, Indonesia. Utopía y Praxis Latinoamericana; ISSN 1316-5216; ISSN-e 2477-9555 Año 25, n Extra 1, 2020, pp.272-281.

19. Damanik, Sarintan Efratani. 2019. Pengembangan Ekowisata Kawah Air Panas Tinggi Raja Sebagai Agen Potensial Untuk Pembangunan Pariwisata Berkelanjutan Di Kabupaten Simalungun. Jurnal AKAR (Aspirasi Karya Anak Rimba: Jurnal Ilmiah Hutan \& Kehutanan). Vol. 8; Issue. 2; 2019.

20. Damanik, Sarintan Efratani. 2019. Perencanaan Pembangunan Kehutanan. Jawa Timur: Uwais Inspirasi Indonesia.

21. Damayanti M, Prafitri RG. 2016. Kapasitas Kelembagaan dalam Pengembangan Desa Wisata (Studi Kasus Desa Wisata Ketenger, Banyumas). Pengembangan Kota. 4 (1) : 7686.

22. Darma SR, Pujani KPL. 2018. Implikasi Perkembangan Pariwisata Terhadap Sosial Ekonomi Masyarakat di Desa Sibunga-
Bunga, Kecamatan Sinembah Tanjung Muda (STM) Hulu, Kabupaten Deli Serdang, Sumatera Utara. Destinasi Pariwisata. 6 (1).

23. Delveza A, Yuliana DR. 2016. Strategi Pengembangan Fasilitas (Amenities) Objek Wisata Panorama Tabek Patah Kabupaten Tanah Datar. Universitas Negeri Padang.

24. Devi AH, Soemanto RB. 2017. Pengembangan Obyek dan Daya Tarik Wisata Alam Sebagai Daerah Tujuan Wisata di Kabupaten Karanganyar. Sosiologi Dilema 32 (1).

25. Dewi UHM, 2013. Pengembangan Desa Wisata Berbasis Partisipasi Masyarakat Lokal di Desa Wisata Jatiluwih Tabanan, Bali. Kawistara. 3 (2) : 129139.

26. Dharma AP, Roslaini. 2020. Peningkatan Kemampuan Kelompok Tani Hutan Hijau Cipruk Sebagai Pramuwisata Pada Materi Amfibi di Desa Gekbrong. IKRAITHABDIMAS. 3 (3) : 198-201.

27. Direkektorat Pariwista. 2009. Prinsip dan Kriteria Ekowisata Berbasis Masyarakat.

28. Direktorat Jenderal Pengembangan Destinasi Pariwisata.

29. Djula B. 2016. Sumber Daya Alam dan Pertumbuhan Ekonomi.

30. Elva, Kaskoyo H, Febryano GI, Yuwono BS. 2017. Kajian Kelembagaan Gabungan Kelompok Tani dalam Program Kemitraan di Kphp Way Terusan. Hutan Tropis. 5 (1).

31. Elwijan FS, Damayanti M. 2017. Pemanfaatan Sumber Daya Alam pada Kawasan Rawan Bencana untuk Kegiatan Pariwisata. Wilayah dan Lingkungan. 5 (2) : 71-82.

32. Hadidja, Golar, Sudhartono A. 2016. Kesiapan Kelembagaan Kelompok Tani Hutan Desa Kawende Kecamatan Poso Pesisir Utara Kabupaten Poso dalam Rencana Pembangunan Hutan Kemasyarakatan. Warta Rimba. 4 (2) : 8291.

33. Hidayat, 2011. Pengelolaan Sumber Daya Alam Berbasis Kelembagaan Lokal Universitas Negeri Medan. Sejarah Citra Lekha XV (1) : 19-32.

34. Hijriati E, Mardiana R. 2014. Pengaruh Ekowisata Berbasis Masyarakat Terhadap Perubahan Kondisi Ekologi, Sosial dan Ekonomi di Kampung Batusuhunan, Sukabumi. Sosiologi Pedesaan. 2 (3) : 146159. 
35. Irwanto, Isyak, Ummu, H., Sarintan E. D., \& Pinondang N. 2020. Pengaruh Lembaga Pemberdayaan Masyarakatnagori Dan Tim Penggerak Pemberdayaankesejahteraan Keluarga Terhadap Pembangunannon Fisik Di Kecamatan Raya. Jurnal Regional Planning, ISSN 2252-553XVol. 9 No. 1 Februari 2020.

36. Kairupan J, Singkoh F, Serang PR. 2018. Pengelolaan Objec Wisata Pantai Baliranggeng Oleh Dinas Pariwisata Kabupaten Kepulauan Siau Tagulandang Biaro. Jurusan Ilmu Pemerintahan 1 (1).

37. Katili SA. 2009. Kebijakan Pemanfaatan dan Pengawasan dalam Pengelolaan Sumber Daya Alam. Legalitas. 2 (1) : 71-80.

38. Kurniawan A. 2012. Pengelolaan Pariwisata Melalui Konsep Community Based Tourism.

39. Latifah S, Afifi M. 2011. Peranan Kelembagaan Bagi Pengembangan Sumber Daya Non Material dalam Menunjang Pembangunan Perdesaan. Universitas Mataram. Sosiohumaniora, 13 (3) : 263-276.

40. Liahmad, Kartika Rusnidita, Yuni Putri Utami, Saleh Sitompul.2021. Financial Factors and Non-Financial to Financial Distress Insurance Companies That Listed in Indonesia Stock Exchange. Budapest International Research and Critics Institute (BIRCI-Journal): Humanities and Social Sciences, 4(1), 1305-1312.

41. Mardiana R, Hijriati E. 2014. Pengaruh Ekowisata Berbasis Masyarakat Terhadap Perubahan Ekologi, Sosial dan Ekonomi di Kampung Batu Suhunan, Sukabumi. Sosiologi Pedesaan. 2 (3) : 146-159.

42. Marpaung R, Agus P, Kansih SH. 2014. Analisis Potensi dan Pengembangan Kawasan Wisata Taman Eden 100 Kecamatan Lumban Julu, Kabupaten Toba Samosir, Sumatera Utara (The Analisys of Potential and Development of Taman Eden 100 Tourism Area, Subdistrict Lumban Julu, District Toba samosir, North Sumatera).

43. Maswandi, Ariman Sitompul. 2020. Tindak Pidana Korupsi Dibalik Kontrak Pengadaan Barang/Jasa, Yogjakarta : K-Media.

44. Maswandi, Ariman Sitompul.2020. Perampasan Aset Hasil Tindak Pidana Pencucian Uang Dengan Asal Pidana Korupsi, Malang : Mazda Media..

45. Mesliani, Surya., Sarintan E. D., Tuahman S., \& Anggiat S. 2019. Pengaruh Kinerja
Pegawai Dinas Sosial Dan Partisipasi Masyarakat Terhadap Pengembangan Wilayah Di Kabupaten Toba Samosir. Jurnal Regional Planning. ISSN 2252-553X. Vol. 8 No.2 Agustus 2019.

46. MN, Sarintan Efratani Damanik, Rozalina. 2021. Influence of Sipinsur Ecotourism Area Business Opportunity on Regional Development in Humbang Hasundutan Regency. International Journal of Business, Economics \& Management. Vol. 4; Issue. 1; page; $130-134$.

47. MRD., Sarintan Efratani Damanik. 2020. Planning Model of Population Education and Environment in State Elementary School in District of Simalungun Regency. International Journal of Advanced Science and Technology. Vol. 29; Issue. 5s; page; 865-873.

48. Muhtadi A, Sitohang SP. 2016. Kelembagaan pengelolaan ekowisata mangrove di Pantai Bali Kabupaten Batu Bara Provinsi Sumatera Utara. Universitas Sumatera Utara. Acta Aquatica. 26-32.

49. Nawawi A. 2013. Partisipasi Masyarakat dalam Pengelolaan Wisata Pantai Depok di Desa Kretek Parangtritis. Universitas Gadjah Mada. Pariwisata 5 (2) : 103-109.

50. Nikoyan A, Kasim S, Uslinawati Z, Yani R. 2020. Peran dan Manfaat Kelembagaan Kelompok Tani Pelestari Hutan dalam Pengelolaan Taman Hutan Raya Nipa-Nipa. Fakultas Kehutanan dan Ilmu Lingkungan Universitas Halu Oleo.16 (1) : 34-39.

51. Noor M. 2017. Analisis Kelembagaan Program Nasional Pemberdayaan Masyarakat Mandiri Perkotaan (PNPM-MP) untuk Penanggulangan Kemiskinan. UNTAG Semarang : 113-124.

52. Nurhudawi, Saleh Sitompul. 2020. Analisis Return Saham Pada Perusahaan Pertambangan Batubara Di Bursa Efek Indonesia. Shar-E: Jurnal Kajian Ekonomi Hukum Syariah. Vol. 6 No. 2 Juli 2020, Hal. 108-116.

53. Nusbantoro JA, Prasodjo A, Apriono M, Saleh C. 2017. Perspektif Pengembangan Pariwisata Rawa Indahdi Desa Wisata "Alas Sumur” Kecamatan Pujer Kabupaten Bondowoso.

54. Payadnya KD. 2008. Kewenangan Pemerintah Daerah dalam Pengelolaan Sumber Daya Alam. Implementasi Kebijakan Otonomi Daerah. 
55. Purwanto. 2013. Valuasi Ekonomi Ekowisata dengan Model Travel Cost dan Dampaknya Terhadap Usaha Kecil Pariwisata. Manajemen dan Kewirausahaan. 15 (1) : 89-102.

56. Putra R. 2018. Pembentukan dan Pengembangan Gabungan Kelompok Tani (Gapoktan). Balai Pengkajian Teknologi Pertanian Kepulauan Riau Badan Penelitian dan Pengembangan Pertanian Kementerian Pertanian.

57. RA Alponita, SE Damanik. 2020. Analisa Vegetasi Pakan Gajah Di Aek Nauli Elephant Conservation Camp (ANECC). Jurnal Akar. Vol. 2; Issue. 2; page; 103-114.

58. Rahayu, S. et al. (2020). Effect Of Work To Family Conflict And Work Stress On Organizational Commitments With Work Satisfaction As Intervening Variables. International Journal For Innovative Research In Multidisciplinary Field. Vol. 6, Issue 7, July - 2020: 10-17. Permono, Iswardono S dan Darmawan. 2010. "Analisis Efisiensi Industri Perbankan di Indonesia (Studi kasus Bank-Bank Devisa di Indonesia Tahun 1991-1996)”. Jurnal Ekonomi dan Bisnis Indonesia. Universitas Gajah Mada. Yogyakarta.

59. Ramadi F. 2016. Strategi Pengelolaan Objek Wisata Istana Kota Rebah Sungai Carang Oleh Dinas Pariwisata dan Kebudayaan Kota Tanjungpinang. Universitas Maritim Raja Ali Haji Tanjungpinang.

60. Rani MPD. 2014. Pengembangan Potensi Pariwisata Kabupaten Sumenep, Madura Jawa Timur (Studi Kasus: Pantai Lombang). 3 (3) : 412-421.

61. Rimbawati MED, Anna F, Basita GS. 2018. Dinamika Kelompok Tani Hutan Agroforestry di Kabupaten Bandung. 14 (1).

62. Sahureka M. 2016. Pemanfaatan Lahan dan Pengelolaan Sumber daya Hutan oleh Masyarakat Sekitar Kawasan Hutan Lindung Gunung Sirimau (Studi Kasus di Desa Hukurila Kota Ambon). DOI:10.30598/jhppk. 58-65.

63. Salakory BJAR. 2016. Pengembangan Ekowisata Berbasis Masyarakat di Kepulauan Banda, Kabupaten Maluku Tengah. 10 (1).

64. Saroinsong BF, Kalangi F. 2016. Teknik pengelolaan sumber daya alam untuk Konservasi diarea pemukiman. Universitas Sam Ratulangi. Abdimas 9 (1).
65. SE Damanik, A Sinurat. 2020. Planning Of Sustainable City Model In Pematangsiantar. Journal Planning. Vol. 29; Issue. 9s; page; 4902-4910.

66. Sitompul, Ariman, et al. 2020. The Criminal Replacement Of Fine In Law Of Money Laundering Number 8 Of 2010 (Case Study In North Sumatera). International Journal Of Creative Research Thoughts. Volume 8 Issue 11, Date of Publication: November 2020.

67. Sitompul, Ariman, Mhd. Nasir Sitompul. 2019. The Combination Of Money Laundering Crime With The Origin Of Narkotics Crime To Islamic Law. Proceeding International Seminar on Islamic Studies Volume 1 Nomor 1 Tahun 2019.

68. Sitompul, Ariman., Maswandi. 2021. Nikah Poliandri Dalam Perpektif Pidana Islam dan Hukum Positif di Indonesia, Malang:Mazda Media.

69. Sitompul, S. (2019). Pengaruh Motivasi Dan Kepemimpinan Terhadap Prestasi Kerja Pada PT. PLN (Persero) Unit Induk Pembangunan II Medan. Jurnal Ilmiah METADATA, 1(2), 93-105.

70. Sitompul, S. (2021). Pengaruh Pengetahuan Label Halal Dan Kesadaran Merek Terhadap Keputusan Pembelian Kosmetik Melalui Rekomendasi Kelompok Sebagai Variabel Moderating. Shar-E: Jurnal Kajian Ekonomi Hukum Syariah, Vol. 7 No. 1 (2021).

71. Sitompul, S. 2018. Pengaruh ukuran perusahaan, kebijakan pendanaan, Risk based capital (RBC), pertumbuhan premi netto dan laba perusahaan terhadap nilai perusahaan pada perusahaan Asuransi yang terdaftar di Bursa Efek Indonesia. Universitas Sumatera Utara.

72. Sitompul, Saleh dan Nasution, Siti Khadijah. 2019. The Effect of Car, BOPO, NPF, and FDR on Profitability of Sharia Commercial Banks in Indonesia. E-ISSN: 2615-3076. Budapest International Research and Critics Institute (BIRCI-Journal) : Humanities and Social Sciences. Vol. 2. No. 3.

73. Sitompul, Saleh dan Siti Khadijah. 2020. Analysis Net Profit, Dividend, Debt, Cash Flow, and Capital Net Working That Influence Investment Decisions on Manufacturing Companies. International Journal of Research and Review. Vol.7; Issue: 3; March 2020. 
Rinal Kusnadi. Management of the natural attractions in the area Simarjarunjung Simalungun North Sumatra province.

74. Sitompul, Saleh. et al. (2021). Pengenalan Dasar-Dasar Investasi Pada Guru-Guru Madrasah Al-Quba. E-Amal Jurnal Pengabdian Kepada Masyarakat, Vol. 1, Issue 3, September - 2021: 343-348.

75. Sitompul, Saleh. et al. (2021). The Influence Of Exchange Rate, Inflation, For The Results Of The Development Assets Of Islamic Banks. Vol. 4, Issue 3, March 2021: 138-148.

76. Sunarko, Eno M, Subyanto PC, Sudarsono A. 2003. Pemanfaatan Sumber Daya Alam di Indonesia
77. Sundra. 2017. Pengelolaan Sumberdaya Hutan, Universitas Udayana, Denpasar. Suryaningsih M, Dwimawanti HI, Rahman FR, 2016. Strategi Pengembangan Pariwisata di Kabupaten Pemalang. Universitas Diponegoro, Semarang.

How to cite this article: Kusnadi R. Management of the natural attractions in the area Simarjarunjung Simalungun North Sumatra province. International Journal of Research and Review. 2021; 8(11): 450-462. DOI: https://doi. org/10.52403/ijrr.20211157 